\title{
Pedigree Analysis of the Hypothermal Recovery of the Effects of Gamma-Rays on Hepatoma Cells
}

\author{
Masatoshi Sakka, Hajim Katsuta* and Toshiko Takaoka* \\ Department of Radiation Research, Tohoku University School \\ of Medicine, Sendai 980 and *Department of Cancer Cell \\ Research, Research Institute of Medical Science, University of \\ Tokyo, Tokyo 108
}

\begin{abstract}
Sakka, M., Katsuta, H. and Takaoka, T. Pedigree Analysis of the Hypothermal Recovery of the Effects of Gamma-Rays on Hepatoma Cells. Tohoku J. exp. Med., 1978, 125 (3), 205-211_Cultured hepatoma cells of the rat were irradiated with 400 to $900 \mathrm{R}$ of gamma-rays. They were kept at room temperature for several hours before transferred to normal culture condition at $37^{\circ} \mathrm{C}$. The pedigree analysis of growing cells recorded by cinematography indicated a variety of lethal and non-lethal recovery events such as a decrease in lethal branch formation and an increase in locomotion. The so-called repair immediately after irradiation has many facets depending upon dose and duration of the low temperature treatment._- cellular radiobiology; pedigree analysis; hypothermia
\end{abstract}

Cultured hepatoma cells, JTC 2, spread themselves on a wall of culture vessel in the intermitotic period. When they are kept at room temperature of $20^{\circ} \mathrm{C}$, they take a form of sphere, instead of spread forms, and the progression in a cell cycle is stopped. It seems likely that adverse effects of irradiation are modified when cells become sphere and stay there for several hours. Therefore an apparent recovery may be expected in a sphere under the hypothermal condition. The purpose of the present experiment is to study early changes observed in growth pedigrees kept under hypothermal condition immediately after irradiation.

\section{Material and Method}

Cultured hepatoma cells JTC 2 derived from AH 130, a line of ascites hepatoma of a rat colony, were irradiated with cobalt gamma-rays. Immediately after irradiation a lot was transferred to normal culture condition under a microscope, which was used as a control. Another one was kept for 3 to $5 \mathrm{hr}$ at room temperature before transferred to the culture box. Under both conditions the cells were photographed by time-lapse cinematography, 1 frame/2 min for more than 4000 frames (5.5 days). Research films were analyzed by a motion analyzer provided by Nac Co. and pedigrees were constructed. The results of observations on the first two generations immediately after irradiation are presented in this paper. For detailed descriptions of materials and methods and the coding of pedigrees, readers are referred to previous reports (Sakka 1974; Sakka, Katsuta and Takaoka 1972, 1975, 1976).

Received for publication, November 28, 1977. 


\section{Results}

Changes in generation zero by irradiation followed by hypothermia are listed in Table 1. From the analysis it was demonstrated that the hypothermal treatment after 400 or $900 \mathrm{R}$ ( $400 \mathrm{R} / \mathrm{hyp}$ otherm or $900 \mathrm{R} / \mathrm{hyp}$ otherm) did not produce significant changes in the time of the first post-irradiation cell divisions. Only in an experiment of $600 \mathrm{R}$ followed by hypothermia for $250 \mathrm{~min}$ (125 frames) (600R/ hypotherm-250), the first post-irradiation cell division delayed significantly. In a series of experiments performed in the spring of 1977 no significant difference was detected in the length of generation zero. Comparison of the length of generation one (number of frames between the first and the second post-irradiation division) is listed in Table 2. No significant difference was detected except a single case of $400 \mathrm{R} /$ hypotherm-312 in which the second post-irradiation division occurred earlier than expected.

TABLE 1. Changes in generation zero by irradiation/hypothermia in JTC-2 cells

\begin{tabular}{|c|c|c|c|c|c|c|c|c|}
\hline Code & $\mathrm{RC6}$ & RA5 & RB21 & $\mathrm{RC} 22$ & SC3 & SA3 & SD4 & SB3 \\
\hline Exposure $(R)$ & \multicolumn{4}{|c|}{$400 \mathrm{R}$} & \multicolumn{2}{|c|}{$600 \mathrm{R}$} & \multicolumn{2}{|c|}{ 900R } \\
\hline Hypothermia & - & $+\left(112^{*}\right)$ & - & $+\left(156^{*}\right)$ & - & $+\left(125^{*}\right)$ & - & $+\left(125^{*}\right)$ \\
\hline $\mathbf{N}$ & 19 & 10 & 14 & 15 & 4 & 14 & 13 & 9 \\
\hline $\mathrm{x}^{*}$ & 641.21 & 986.10 & 1065.00 & 1059.33 & 379.75 & 779.29 & 648.31 & 635.11 \\
\hline$V^{*}$ & 143,417 & 364,147 & $1,209,572$ & 757,488 & 66,555 & 138,770 & 80,172 & 27,853 \\
\hline$t_{0}$ & \multicolumn{2}{|c|}{1.64} & \multicolumn{2}{|c|}{0.01} & \multicolumn{2}{|c|}{2.58} & \multicolumn{2}{|c|}{0.14} \\
\hline $\mathrm{C}$ & \multicolumn{2}{|c|}{0.17} & \multicolumn{2}{|c|}{0.65} & \multicolumn{2}{|c|}{0.63} & \multicolumn{2}{|c|}{0.67} \\
\hline & \multirow{2}{*}{\multicolumn{2}{|c|}{$\begin{array}{r}12.80 \\
\text { Yes }\end{array}$}} & \multirow{2}{*}{\multicolumn{2}{|c|}{$\begin{array}{r}22.75 \\
\text { Yes }\end{array}$}} & \multicolumn{2}{|c|}{7.00} & \multicolumn{2}{|c|}{19.60} \\
\hline $\mathbf{H}_{0}: \mu_{1}=\mu_{2}$ & & & & & & 0 & & \\
\hline
\end{tabular}

* Presented by number of frames of cinematographs, 1 frame/2 min.

TABLE 2. Change of generation one by irradiation/hypothermia in JTC-2 cells

\begin{tabular}{|c|c|c|c|c|c|c|c|c|}
\hline Code & RC6 & RA5 & RB21 & $\mathrm{RC} 22$ & SC3 & SA3 & SD4 & SB3 \\
\hline Exposure (R) & \multicolumn{4}{|c|}{$400 \mathrm{R}$} & \multicolumn{2}{|c|}{$600 \mathrm{R}$} & \multicolumn{2}{|c|}{$900 \mathrm{R}$} \\
\hline Hypothermia & - & + & - & + & - & + & 一 & + \\
\hline $\mathrm{N}$ & 14 & 11 & 15 & 10 & 4 & 5 & 13 & 5 \\
\hline $\bar{x}^{*}$ & 912.29 & 804.73 & 1263.87 & 858.80 & 868.50 & 917.60 & 1193.62 & 763.60 \\
\hline$V^{*}$ & 94,634 & 17,544 & 153,320 & 19,605 & 115,476 & 64,458 & 421,624 & 213,508 \\
\hline$t_{0}$ & \multicolumn{2}{|c|}{1.18} & \multicolumn{2}{|c|}{3.67} & \multicolumn{2}{|c|}{0.24} & \multicolumn{2}{|c|}{1.57} \\
\hline $\mathrm{C}$ & \multicolumn{2}{|c|}{0.81} & \multicolumn{2}{|c|}{0.84} & \multicolumn{2}{|c|}{0.65} & \multicolumn{2}{|c|}{0.43} \\
\hline$\phi$ & \multicolumn{2}{|c|}{18.49} & \multicolumn{2}{|c|}{18.78} & \multicolumn{2}{|c|}{$\begin{array}{r}5.47 \\
\text { Yes }\end{array}$} & \multicolumn{2}{|c|}{10.35} \\
\hline $\mathrm{H}_{0}: \mu_{1}=\mu_{2}$ & \multicolumn{2}{|c|}{ Yes } & \multicolumn{2}{|c|}{ No } & \multicolumn{2}{|c|}{ Yes } & \multicolumn{2}{|c|}{ Yes } \\
\hline
\end{tabular}

* Presented by number of frames of cinematographs, 1 frame $/ 2 \mathrm{~min}$.

A cell in a pedigree usually spreads itself on a vessel wall during the intermitotic phase and then turns into a normal cell in the mitotic period. It is interesting to know if hypothermia brings on a change in morphology in the cell cycle, i.e., relative length of the round and spread cell periods. The recovery of mammalian cells after irradiation, either repair of sublethal damage or potentially 
lethal damage, takes place soon after irradiation without cell division. Time-lapse photography of cells immediately after irradiation will provide a good material for the analysis of early post-irradiation recovery when the relative length of round and spread cell changes significantly after hypothermal treatment. The period of round cell state immediately before and after the first post-irradiation cell division was measured and the analytical data are listed in Table 3. Hypothermia exercised no influence on the round cell period except for an example of $600 \mathrm{R}$. Observations for the second division are not listed in the table, because most cells were killed in early generation by large doses of gamma-rays. It was frequently observed that a small dose of stimulus accelerated cellular activities such as locomotion, rotation, pseudopod formation and cytoplasmic streaming. Post-irradiation recovery of cells which occurred independently on nuclear activity may be related to cytoplasmic activity. As an estimate of cytoplasmic activity we measured the capacity of locomotion of cells. In the following experiments, the frequency of cells escaped from the observation field, i.e., the rate of out branches (Rō) is listed. Results are given in Table 4 in which hypothermia alone applied to control cells gave rise to

TABLE 3. Duration of round cell state before and after first post-irradiation division in pedigrees in which all cells are killed

\begin{tabular}{|c|c|c|c|c|}
\hline Code & $\mathrm{SC} 3$ & SA3 & SD4 & SB3 \\
\hline Exposure (R) & \multicolumn{2}{|c|}{$600 \mathrm{R}$} & \multicolumn{2}{|c|}{$900 \mathrm{R}$} \\
\hline Hypothermia & - & + & - & + \\
\hline \multicolumn{5}{|l|}{ Before division } \\
\hline $\mathrm{N}$ & 13 & 11 & & $\begin{array}{c}8 \\
164.00\end{array}$ \\
\hline $\begin{array}{l}\bar{x}^{*} \\
V^{*}\end{array}$ & $\begin{array}{r}46.00 \\
117.00\end{array}$ & $\begin{array}{r}56.36 \\
2,053.85\end{array}$ & $\begin{array}{c}188.81 \\
103,116.96\end{array}$ & $\begin{array}{c}164.00 \\
113,157.43\end{array}$ \\
\hline & \multirow{2}{*}{\multicolumn{2}{|c|}{-0.65}} & \multirow{2}{*}{\multicolumn{2}{|c|}{0.17}} \\
\hline $\begin{array}{l}t_{0} \\
\mathrm{C}\end{array}$ & & & 0.31 & \\
\hline$\phi$ & \multicolumn{2}{|c|}{0.17} & \multicolumn{2}{|c|}{$\begin{array}{r}13.44 \\
\text { Yes }\end{array}$} \\
\hline $\mathrm{H}_{0}: \mu_{1}=\mu_{2}$ & \multicolumn{2}{|c|}{ Yes } & & \\
\hline Aller $\mathrm{N}$ & 6 & 23 & 31 & 17 \\
\hline $\bar{x}^{*}$ & 20.33 & 34.30 & 35.09 & 52.05 \\
\hline $\mathrm{V}^{*}$ & 19.47 & 952.22 & $2,952.09$ & $3,272.93$ \\
\hline$t_{0}$ & \multirow{2}{*}{\multicolumn{2}{|c|}{-2.09}} & \multicolumn{2}{|c|}{-1.00} \\
\hline $\mathrm{C}$ & & & \multicolumn{2}{|c|}{0.33} \\
\hline$\phi$ & \multirow{2}{*}{\multicolumn{2}{|c|}{$\begin{array}{r}24.82 \\
\text { No }\end{array}$}} & \multirow{2}{*}{\multicolumn{2}{|c|}{$\begin{array}{r}31.56 \\
\text { Yes }\end{array}$}} \\
\hline $\mathbf{H}_{0}: \mu_{1}=\mu_{2}$ & & & & \\
\hline
\end{tabular}

* Presented by number of frames of einematographs, 1 frame/2 min.

TABLE 4. Effect of irradiation/hypothermia on cell locomotion

\begin{tabular}{|c|c|c|c|c|c|c|c|c|}
\hline Code & RB20 & $\mathrm{RC} 2 \mathrm{I}$ & RB21 & $\mathrm{RC} 22$ & $\mathrm{SC} 3$ & $\mathrm{SA} 3$ & SD4 & SB3 \\
\hline Exposure (R) & \multicolumn{2}{|c|}{ - } & \multicolumn{2}{|c|}{$400 \mathrm{R}$} & \multicolumn{2}{|c|}{$600 \mathrm{R}$} & \multicolumn{2}{|c|}{$900 \mathrm{R}$} \\
\hline $\begin{array}{l}\text { Hypothermia } \\
\text { Ró⿱ }^{*}\end{array}$ & $\overline{13 / 131}$ & $\begin{array}{c}+ \\
12 / 246\end{array}$ & $\overline{11 / 106}$ & $\stackrel{+}{+}$ & $\overline{1 / 24}$ & $\begin{array}{c}+ \\
12 / 66\end{array}$ & $\overline{6 / 89}$ & $\begin{array}{c}+ \\
20 / 54\end{array}$ \\
\hline Difference & & $S$ & & & \multicolumn{2}{|c|}{$\mathrm{S}$} & \multicolumn{2}{|c|}{$\mathrm{s}$} \\
\hline
\end{tabular}

* Number of out branches divided by all branches. 
TABLE 4-2. Effect of irradiation/hypothermia on cell locomotion

\begin{tabular}{|c|c|c|c|}
\hline Code & SD9 & SDl0 & SAI0 \& 12 \\
\hline Exposure $(\mathbf{R})$ & 0 & \multicolumn{2}{|c|}{$600 \mathrm{R}$} \\
\hline Hypothermia & - & - & + \\
\hline Ró & $32 / 217$ & $67 / 293$ & $70 / 454$ \\
\hline Difference & & & $\mathrm{s}$ \\
\hline
\end{tabular}

decrease in Rō. It is explained by suppression of cellular activity by hypothermia. Rō's were increased by $600 \mathrm{R} /$ hypotherm and $900 \mathrm{R} /$ hypotherm. It is demonstrated in Table 4-2 that irradiation of $600 \mathrm{R}$ increased $\mathrm{Ro}$ but $600 \mathrm{R} / \mathrm{hypotherm}$ did not produce a surplus increase in the rate. Small doses of radiation followed by hypothermia make an increase of cell movement. Associated cell death, growth retardation and metastasis are to be studied in future.

Irradiation and/or hypothermia induced a change in Rō in pedigrees. Significant difference in the time of escape out of the field was tested. Only 600R/ hypotherm had significant effects. No remarkable effect was observed when a dose was increased to $900 \mathrm{R}$ (Table 5).

TABLE 5. Time of occurrence of out branches

\begin{tabular}{|c|c|c|c|c|}
\hline Code & SD9 & SD10 & SB9 & SA8 \\
\hline Exposure (R) & - & $600 \mathrm{R}$ & \multicolumn{2}{|c|}{$900 \mathrm{R}$} \\
\hline Hypothermia & - & - & - & + \\
\hline $\mathrm{N}$ & 33 & 67 & 26 & 27 \\
\hline$\overline{\mathrm{x}}^{*}$ & $2,606.09$ & $1,161.49$ & $1,117.53$ & $1,356.01$ \\
\hline $\mathrm{V}^{*}$ & $1, \underbrace{381,917.40}$ & $1,349,069.31$ & $6 \underbrace{05,805.69}$ & $918,343.87$ \\
\hline $\mathbf{t}_{\mathbf{0}}$ & \multirow{2}{*}{\multicolumn{2}{|c|}{$\begin{array}{l}3.74 \\
0.68\end{array}$}} & \multicolumn{2}{|c|}{$\begin{array}{l}1.00 \\
0.59\end{array}$} \\
\hline $\mathrm{C}$ & & & & \\
\hline $\begin{array}{c}\phi \\
\mathrm{H}_{0}: \mu_{1}=\mu_{2}\end{array}$ & \multicolumn{2}{|c|}{62.49} & \multicolumn{2}{|c|}{49.72} \\
\hline
\end{tabular}

* Presented by number of frames of cinematographs, 1 frame $/ 2 \mathrm{~min}$.

Degree of post-irradiation recovery is usually measured by survival fraction ratios. When cellular activity is observed in pedigrees, cell death is measured at least by two parameters; one is the lethality or survival rate and the other is the time of death. Test of significance of the lethality rate is given in Table $6.900 \mathrm{R} /$ hypotherm increased the survival rate but $600 \mathrm{R} /$ hypotherm had an opposite effect. The recovery in this example occurred in large dose range. Time of cell death for each cell was pooled and analyzed irrespective of generations after irradiation in which cells died. As is seen in Table 7 only 400R/hypotherm delayed the time of death preventing early death after irradiation. This type of recovery occurred only in low dose range. Hypothermia had no protective effect on cells received more than $600 \mathrm{R}$ when the time of death post-irradiation was compared. 
TaBle 6. Comparison of lethality rate

\begin{tabular}{|c|c|c|c|c|c|c|c|}
\hline Code & SD4 & SB3 & SD9 & SD10 & $\mathrm{SAl0} \& 12$ & SB9 & SA8 \\
\hline Exposure (R) & \multicolumn{2}{|c|}{$900 \bar{R}$} & - & \multicolumn{2}{|c|}{$900 \bar{R}$} & \multicolumn{2}{|c|}{$600 \bar{R}$} \\
\hline Hypothermia & - & + & - & - & + & - & + \\
\hline \multicolumn{8}{|l|}{$\begin{array}{l}\text { No. of completely } \\
\text { lethal pedigrees }\end{array}$} \\
\hline No. of all pedigrees & $13 / 19$ & $7 / 23 \downarrow$ & $1 / 14$ & $13 / 55 \downarrow$ & $53 / 115$ & $36 / 67$ & $11 / 42 \downarrow$ \\
\hline No. of lethal branches & & & & & & & \\
\hline No. of all branches & $33 / 73$ & $17 / 54 \downarrow$ & $9 / 221$ & $58 / 307 \downarrow$ & $159 / 488$ & $62 / 147$ & $26 / 101 \downarrow$ \\
\hline
\end{tabular}

$\downarrow$ Means significant decrease

TABLE 7. Time of cell death (in number of frames)

\begin{tabular}{|c|c|c|c|c|c|}
\hline \multicolumn{2}{|c|}{ Code } & RB21 & $\mathrm{RC} 22$ & SC3 & SA3 \\
\hline \multirow{2}{*}{\multicolumn{2}{|c|}{$\begin{array}{l}\text { Exposure (R) } \\
\text { Hypothermia }\end{array}$}} & \multicolumn{2}{|c|}{$400 \bar{R}$} & \multicolumn{2}{|c|}{$600 \mathrm{R}$} \\
\hline & & - & + & - & + \\
\hline \multirow{2}{*}{\multicolumn{2}{|c|}{$\begin{array}{l}\overline{\mathrm{x}}^{*} \\
\mathrm{~V}^{*}\end{array}$}} & $2,417.78$ & $3,052.82$ & $2,207.18$ & $2,426.40$ \\
\hline & & $712,636.30$ & $564,886.78$ & $1,455,238.96$ & $555,599.73$ \\
\hline \multicolumn{2}{|c|}{$\begin{array}{l}\mathrm{t}_{0} \\
\mathrm{C}\end{array}$} & \multicolumn{2}{|c|}{$\begin{array}{r}-2.35 \\
0.54\end{array}$} & \multicolumn{2}{|c|}{-0.55} \\
\hline \multirow{2}{*}{\multicolumn{2}{|c|}{$\begin{array}{c}\phi \\
\mathrm{H}_{0}: \mu_{1}=\mu_{2}\end{array}$}} & \multicolumn{2}{|c|}{32.92} & \multicolumn{2}{|c|}{14.20} \\
\hline & & \multicolumn{2}{|c|}{ No } & \multicolumn{2}{|c|}{ Yes } \\
\hline SD10 & SAlO & SB9 & SA8 & SD4 & SB3 \\
\hline \multicolumn{2}{|c|}{$600 \mathrm{R}$} & \multicolumn{2}{|c|}{$900 \mathrm{R}$} & \multicolumn{2}{|c|}{$900 \mathrm{R}$} \\
\hline- & + & - & + & - & + \\
\hline $2,223.95$ & $2,468.69$ & $1,732.05$ & $2,080.31$ & $2,222.21$ & $2,125.88$ \\
\hline $896,381.77$ & $852,507.79$ & $1,146,434.37$ & $884,233.58$ & $1,105,026.48$ & $472,924.78$ \\
\hline \multicolumn{2}{|c|}{-1.54} & \multicolumn{2}{|c|}{-1.52} & \multicolumn{2}{|c|}{0.38} \\
\hline & & \multicolumn{2}{|c|}{0.32} & \multicolumn{2}{|c|}{0.53} \\
\hline \multicolumn{2}{|c|}{117.83} & \multirow{2}{*}{\multicolumn{2}{|c|}{$\begin{array}{r}52.89 \\
\text { Yes }\end{array}$}} & \multirow{2}{*}{\multicolumn{2}{|c|}{$\begin{array}{r}42.54 \\
\text { Yes }\end{array}$}} \\
\hline \multicolumn{2}{|c|}{ Yes } & & & & \\
\hline
\end{tabular}

* Presented by number of frames of cinematographs, 1 frame/2 min.

In summary, irradiation/hypothermia had a variety of restorative effects on cell pedigrees. Statistically significant effects are as follows:

1. $0 \mathrm{R} /$ hypotherm; decrease in the rate of out branches.

2. $400 \mathrm{R} /$ hypotherm; inhibition of delay of generation one and delay of death.

3. $900 \mathrm{R} /$ hypotherm; decrease in lethality rate.

On the other hand, significant adverse effects of hypothermia are also apparent such as:

4. $600 \mathrm{R} /$ hypotherm; increase in lethality rate.

As for the following observations, however, it is difficult to classify whether the effects are adverse or beneficial.

5. 600R/hypotherm; dealy of round cell state after the first post-irradiation division, increase in the rate of out branches, early occurrence of out branches. 
6. $900 \mathrm{R} /$ hypotherm; increase in the rate of out branches.

\section{Discussion}

It was Phillips and Tolmach (1966) who tested the effect of low temperature on the repair of potentially lethal damage of irradiated HeLa S3 cells. They said "When cultures were irradiated in early G1 and incubated for various length of time at $29^{\circ} \mathrm{C}$, at which temperature cell progression is markedly slowed but cells are not killed, ... A s second set of plates was incubated at $29^{\circ} \mathrm{C}$ for $4 \mathrm{hr}$ after irradiation. Although the depression in survival brought about by incubation at this temperature is not large, it is reproducible." Low temperature itself has adverse effects on colony forming ability of Chinese hamster cells (Nelson, Kruuv, Koch and Frey 1971). Cells were stored for 0 to 14 days and survival curves were constructed with temperature $\left(5^{\circ}\right.$ to $\left.25^{\circ} \mathrm{C}\right)$ as a parameter. At $5^{\circ} \mathrm{C}$, mean lethal dose $\left(\mathrm{D}_{0}\right)$ was 2.2 days and the intercept of survival curve to dose zero(n) was 3.6. $\mathrm{D}_{0}$ decreased and $\mathrm{n}$ increased gradually as temperature shifted higher. Watanabe and Okada (1967) observed the effect of temperature on growth rate of L $5178 \mathrm{Y}$ leukemia cells of the mouse cultured in vitro. When cells were cultured at $31^{\circ} \mathrm{C}$ instead of $37^{\circ} \mathrm{C}$ all generations delayed, with especially remarkable delay in G1, but synchronization was unsuccessful. Winans et al. (1972) reported the effect of low temperature on the repair of potentally lethal damage of Chinese hamster cells in culture. Cells were irradiated at $20^{\circ} \mathrm{C}$ for various periods of time. The results illustrated that no repair was observed for at least $60 \mathrm{~min}$, and an increase in survival occurred only at 100-120 min as the cells started moving into $\mathrm{Gl}$; the damage was repaired after the cells had entered G1. Evans et al. (1974) tested the modification of the repair of potentially lethal damage by post-irradiation temperature. Whatever the nature of the lesion involved in the recovery process, they can be held, apparently without modification, for at least $6 \mathrm{hr}$ at 4 and $25^{\circ} \mathrm{C}$ and then repaired. Ohyama et al. (1974) reported on the effects of post-irradiation temperature. Rat thymocyte suspensions were exposed to $\mathrm{x}$-rays $(500$ to 1000 $\mathrm{R})$. Lowering the incubation temperature from $37^{\circ} \mathrm{C}$ to $25^{\circ} \mathrm{C}$ prevented the appearance of dead cells. Koch and Burki (1977) observed the remarkable effect of low tempature storage on the repair of potentially lethal damage of Chinese hamster cells. One of the most interesting aspects of the cold effects is that if the cells were warmed to room temperature or $37^{\circ} \mathrm{C}$ for as short as $10 \mathrm{~min}$ after irradiation, no subsequent decrease in survival with storage at $4^{\circ} \mathrm{C}$ was observed. They said "Since there was no difference in survival for cells irradiated at $37^{\circ} \mathrm{C}$, this implies that whatever agent responsible for the synergistic killing has a very short half-life at higher temperature."

\section{References}

1) Evans, R.G., Bagshaw, M.A., Gordon, L.F., Kurjia, S.D. \& Hahn, G.M. (1974) Modification of recovery from potentially lethal $x$-ray damage in plateau phase Chinese hamster cells. Radiat. Res., 59, 597-605. 
2) Koch, C.J. \& Burki, H.J. (1977) Enhancement of X-ray induced potentially lethal damage by low temperature storage of mammalian cells. Brit. J. Radial., 50, 290-293.

3) Nelson, R.J., Kruuv, J., Koch, C.J. \& Frey, H.E. (1971) Effect of sub-optimal temperature on survival of mammalian cells. Exp. Cell Res., 68, 247-252.

4) Ohyama, H., Yamada, T. \& Inoué, Y. (1974) Effect of post-irradiation temperature on viability of rat thymocytes. Int. J. Radiat. Biol., 26, 535-546.

5) Phillips, R.A. \& Tolmach, L.J. (1966) Repair of potentially lethal damage in Xirradiated HeLa cells. Radiat. Res., 29, 413-432.

6) Sakka, M. (1974) On coding of pedigrees of dividing cells. Nippon Acta radiol., 34, 704-708. (Japanese)

7) Sakka, M., Katsuta, H. \& Takaoka, T. (1972) Pedigree analysis of growth inhibition of rat hepatoma cells, Culb TC, after gamma irradiation. Tohoku J. exp. Med., 106, 275-284.

8) Sakka, M., Katsuta, H. \& Takaoka, T. (1975) Kinetics of microcolonies of cultured mammalian cells after gamma irradiation. Tohoku J. exp. Med., 117, 299-309.

9) Sakka, M., Katsuta, H. \& Takaoka, T. (1976) Kinetics of microcolonies of cultured mammalian cells after bleomycin treatment. Tohoku J. exp. Med., 120, 201-207.

10) Watanabe, I. \& Okada, S. (1967) Effects of temperature on growth rate of cultured mammalian cells (L 5178 Y). J. Cell Biol, 32, 309-323.

11) Winans, L.E., Dewey, W.C. \& Dettor, C.M. (1972) Repair of sublethal and potentially lethal damage on synchronous Chinese hamster cells. Radiat. Res., 52, 333-351. 